\title{
Nursing schools curricula: good hand hygiene guaranteed?
}

\author{
DA De Wandel ${ }^{1,2^{*}}$, S Blot $^{2}$, D Vogelaers ${ }^{2}$ \\ From 3rd International Conference on Prevention and Infection Control (ICPIC 2015) \\ Geneva, Switzerland. 16-19 June 2015
}

\section{Introduction}

Hand hygiene compliance is poor among graduated nurses. Hand hygiene behaviour is complex and shows great variation that can be attributed to the healthcare worker's educational background.

\section{Objectives}

The objective was to quantify the level of attention given to hand hygiene in the course curricula of nursing schools in Belgium.

\section{Methods}

A questionnaire was distributed during the Federal Public Service's (FPS) 'hand hygiene campaign introduction session 2011' for nursing school staff involved in teaching hand hygiene.

\section{Results}

Response was $100 \%(\mathrm{n}=49)$. The attending teachers represented $53 \%$ of all Belgian nursing schools. With each year of education, HH related knowledge (1st: $98 \%$, 2nd: $49 \%$, 3rd: 29\%), attitude and skills (1st: $98 \%$, 2nd: 71\%, 3rd: 55\%) receive less attention. Competencies are evaluated during clinical practice (90\%), by means of written exams (90\%), skills tests at school (37\%) or 'other' (18\%). Most popular teaching methods include live demonstration (98\%), skills training sessions (71\%) and video demonstration (59\%). Courses are being held up to date using books (64\%), publications of the Superior Health Council (44\%), scientific publications (26\%) and the FPS HH website (16\%). Sixty-one per cent of the study books have not been updated in the past two years. The average time spent on infection control and hand hygiene was

${ }^{1}$ Faculty of Education, Health \& Social Work, University College Ghent, Belgium

Full list of author information is available at the end of the article respectively $19.68 \mathrm{hrs}(\mathrm{sd} 14.18$, $\min 2 \mathrm{max} 64)$ and $7.07 \mathrm{hrs}$ (sd 6.98, min $2 \max 25$ ).

\section{Conclusion}

Hand hygiene education in Belgium shows great variation. Hand hygiene competencies are not systematically acquired nor assessed during the 3-year course. Moreover, teaching and assessment methods show considerable room for innovation.

\section{Disclosure of interest}

None declared.

\section{Authors' details}

${ }^{1}$ Faculty of Education, Health \& Social Work, University College Ghent, Belgium. 'Faculty of Medicine and Health Sciences, Ghent University, Ghent, Belgium.

Published: 16 June 2015

doi:10.1186/2047-2994-4-S1-P282

Cite this article as: De Wandel et al:: Nursing schools curricula: good hand hygiene guaranteed? Antimicrobial Resistance and Infection Control 2015 4(Suppl 1):P282.

Submit your next manuscript to BioMed Central and take full advantage of:

- Convenient online submission

- Thorough peer review

- No space constraints or color figure charges

- Immediate publication on acceptance

- Inclusion in PubMed, CAS, Scopus and Google Scholar

- Research which is freely available for redistribution 